\title{
Technical and Implementation Issues in Reading Literacy Interactive Games
}

\author{
Gopal R.Mahalingam, Norazrena Abu Samah, Khairul Anuar Abdul Rahman, Dayana Farzeeha \\ Ali, Abdul Halim Abdullah, Zakiah Mohamad Ashari, Nurul Farhana Jumaat, Hemanathan \\ Harikrishnan
}

\begin{abstract}
The technology-based learning process is able to influence pupils on learning and teaching, especially the use of interactive games can transform the way learning of problematic learners in reading skills. Although interactive games are said to be very effective in learning but there are still many technical and implementation shortcomings on remedial education students which identified as slow learners. This paper focuses on technical and implementation issues which restrict the effective integration of Reading Literacy Interactive Games (RLIG) in learning of reading skill among slow learners. The aim of this study is to investigate the critical issues and develop the effective RLIG in order to fulfill the slow learners' needs. Therefore, a need-analysis was conducted to investigate the issues of technical and implementation of RLIG among slow learners. The findings revealed that there are many technical and implementation issues that restricted slow learners from adapting RLIG in the process of teaching and learning. The findings of this research can assist educators to improve the development of RLIG by incorporating relevant pedagogical approaches and game-based features in the development process.
\end{abstract}

Keywords: Interactive Games, Reading Literacy, Slow Learners.

\section{INTRODUCTION}

According to Gabriela (2016), technology in education refers to the introduction of game design elements and fun experiences in designing the learning process. Technology has been used to support learning in various contexts and subject areas as well as to address attitudes, activities and related behaviors such as participation, collaboration, self-assessment, completion of tasks, making evaluation easier and more effective, integration of research exploration to learn, and empower creativity (Wendy, 2016). This statement is supported by Karl (2016), in his study that the use

Revised Version Manuscript Received on April 19, 2019.

Gopal R.Mahalingam, School of Education,Faculty of Social Sciences and Humanities UTM, Malaysia. (mpgopal12@gmail.com)

Norazrena Abu Samah, School of Education,Faculty of Social Sciences and Humanities UTM, Malaysia.

Khairul Anuar Abdul Rahman, School of Education,Faculty of Social Sciences and Humanities UTM, Malaysia.

Dayana Farzeeha Ali, School of Education,Faculty of Social Sciences and Humanities UTM, Malaysia.

Abdul Halim Abdullah, School of Education,Faculty of Social Sciences and Humanities UTM, Malaysia.

Zakiah Mohamad Ashari, School of Education,Faculty of Social Sciences and Humanities UTM, Malaysia.

Nurul Farhana Jumaat, School of Education,Faculty of Social Sciences and Humanities UTM, Malaysia

Hemanathan Harikrishnan, School of Education,Faculty of Social Sciences and Humanities UTM, Malaysia. of games in education can reinforce the concept of the course and enhance the learning experience and disseminate information quickly and accurately to facilitate learning. In his study, Hamari (2014), said the use of games improves understanding and improves student focus on learning and teaching (L\&T). Cheong (2014), states that the use of game applications is a good resource in developing reading skills. It is also supported by Kulik et al., (2014), who said that reading application-based reading helps in enhancing student interaction with text. Although there are many studies related to the use of games in overcoming the problem of reading (Salleh, 2012; Sharifah, 2015), there are still many reading difficulties among primary school students. This is because, the approach of existing interactive games of reading does not emphasize the understanding of the word and links the previous knowledge with new information among the students.

\section{GAME BASED LEARNING IN EDUCATION}

Kiryakova (2016) explains that there are some differences between interactive games in the market with game applications used in the classroom. An interactive games in the market, players play game apps to achieve game objectives solely while in classes pupils playing game apps to achieve certain learning objectives (Kiryakova, 2016). According to Kiryakova (2016), market interactive games make players will move from level to level based on achievement in the game, while in class pupil must pass the prerequisite course and show some level of understanding before moving to the next level. Thus, learning using interactive games is able to alter the way learning disability students learn reading skills (Olsson, 2016). Reading is one of the most challenging areas in the education system (Harvey, 2015). The growing demand for high literacy levels in our digital society makes this problem more serious (Snow, 2017). Therefore, the Ministry of Education Malaysia (MOEM) seeks to integrate technology in the field of language to reduce reading problems among students (MOEM, 2012). Exley (2014), expresses quiz games, matches, word search and scrabble games based on technology approaches can solve reading problems. 


\section{TECHNICAL ISSUES IN RLIG}

Gopal (2017), Mekler et al., (2015) and Liu et al., (2014) found that interactive games were able to solve reading problems. While Teele (2018), and Corey (2016), said that designs of existing interactive games did not emphasize the learning experience of the pupils cause students unable to achieve reading literacy. Oczkus (2017), states that learning objectives will be achieved if interactive games are well designed.

Elements of game design plays an important role in the success of an interactive game-based learning (Kapp, 2012). Most existing games that do not have user-friendly design elements cause players to not get the problem solving idea. Shaffer (2015), states that the size of the letters in the game is too small when students only use notebooks provided by the school, namely 1 Malaysia netbook. The size of the buttons in the game is also quite small even some of the buttons are in the form of text (Peterson, 2016). Students are confused with the words in the button because the students have reading problems. Kapp (2012), states that the design of a game needs to be user-friendly to users. Interactive games of alphabetical and words have problems in form of clarity and allows players to quickly despair due to obscure instructions (Wolfe, 2012). In addition, Shetzer (2015), explains that the way of sound the words or letters in existing interactive games are quite different from Malaysian style. In addition, some of existing interactive games have some mistakes in the sound of the letters due to the use of the computer (Dahlan, 2017) and the voice of sound also confusing pupils (Pun, 2014).Crawford (2013), states that the reading skills game has no effective interactive elements. According to Yip (2016), lack of play elements while learning also causes students not to be interested in learning and less actively engaging in learning. Following that, Diamond (2017), asserted that existing games have design problems in terms of responsiveness. This causes the pupil unable to play the game quickly. Finn (2016), states that students will be disappointed if they wait long to get responds. This is supported by Fallon (2015), stating that students will be easily get bored if the game does not respond immediately.

\section{IMPLEMENTATION ISSUES IN RLIG}

According to Ismail (2017), games in education the tools of social interaction and contribute to cognitive development in early childhood education. On the other hand, Ralph et.al (2016), said that most interactive games in the market did not help the cognitive development of pupils due to less emphasis of pedagogical. This is because, most games in the market are not designed based on certain learning skills (Pratt, 2016). Acceptance of knowledge is effective at the age of four to eight years but the element of acceptance of knowledge, especially the content of learning is less emphasized in most interactive games in the market (Perry, 2015). While Majid (2016), states that content in existing interactive games for reading literacy does not follow curriculum standards according to student's level. This causes the student not to build deeper knowledge (Marzano, 2016).

One of the biggest problems in an existing interactive game is learning content in interactive games varies by country
(Blake, 2015). Othman (2015), states that the content of Malay interactive games of Indonesia is different from Malaysia. In Malaysia, learning content for reading literacy is divided into 12 reading literacy constructs. Therefore, the use of interactive games designed by Indonesian designers is not suitable to address reading literacy problems in Malaysia (Amir, 2016). Furthermore, interactive games in the market are in the form of games only and do not have any game-form learning activities (Anglin et al., 2016, Armstrong, 2015) such as letter-matching activities with sound and fill in the blanks. Furthermore, most interactive games for reading literacy in English subjects (Zamri, 2017). This adds to the problem of reading the Malay language.

Next, in the existing interactive game the element of challenge is less emphasized (Gibson, 2015). The lack of a challenging element allows the construction of knowledge to a high level will be limited (Prensky, 2017). The challenge element in the game is an element that causes players to be interested in learning (Kapp, 2012). According to Perry's theory the interactive game needs to be designed with three levels namely the level of play, the level of playing and the player's level. This means that pupils will go through a low level such as easy to play or an introduction, the medium level has medium level games and high levels of pupils going through various challenges such as high-level questions or challenging playing methods. According to Esposito (2015), the elements of challenge in games need to be a continuation of learning skills as emphasized in cognitive theory. Craik (2015), states that the lack of a description of the learning content early in the game allows students not to know the direction, the skills to learn and the challenges to face. As a result, students unable to develop creativity and cultivate learning interest because of the less challenging element of the game (Schifter, 2013). This opinion is supported by Figueroa (2015), saying that the lack of challenge elements in the game is difficult to stimulate players' thinking to solve problems unaware and they do not apply some of the concepts and skills learned.

\section{V.PURPOSE OF THE STUDY}

This paper focuses on the learning of reading literacy. The structure of this paper begins with fact-finding using the interview method, which consists of a seven step process. The sample interview comprises a total of five remedial education teachers. All of them are selected based on their experience in teaching remedial education especially reading literacy. The interview has been staggered into four perspectives: (1) Student's achievement in reading literacy, (2) Existing interactive games of reading literacy problems and (3) Student's learning engagement towards interactive game based learning of reading literacy. 


\section{METHOD}

For the preliminary investigation the interviewing process method which consists of seven steps is used. Figure 1, will explain how the procedure has been carried out in accordance to the setting in designing interactive game, for reading literacy.

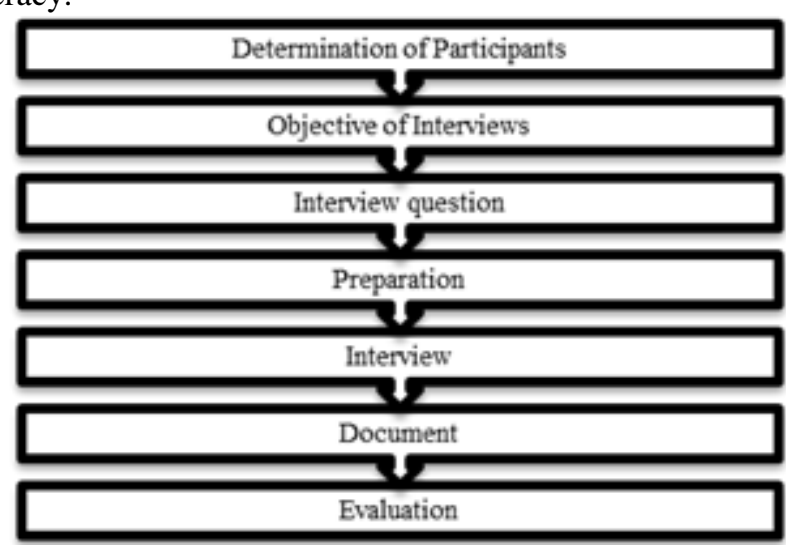

Fig. 1. Interviewing Process

The interview is structured in three sections such as

a. Student's achievement in reading literacy education

This refers to the 2019 mid-term screening test provided by Remedial Education Sector, MOEM. The focus is on level one students who are fail to achieve the first three construct of reading literacy.

b. Existing interactive games of reading literacy problems

This part is to identify a technical and implementation problems of interactive games of reading literacy as experienced among the teachers during their delivery of reading literacy learning in the classroom.

c. Student's learning engagement towards interactive game based learning of reading literacy

This part is to identify the teacher's experience with students' learning engagement during class. It also identifies the student's motivation towards learning area.

\section{RESULTS AND DISCUSSION}

The table I summarizes the teachers' responses into a few listed themes. This list of themes will be discussed further in the findings section. Most of the teachers' responses are similar perceptions on students' achievements and problems as experienced in interactive game based L\&T. The teachers explain in general on the students' attitudes towards reading literacy study. Interactive game is one of the tools proposed by the teachers that can be of help to support the students' learning.

Table I : Table of Analysis

\begin{tabular}{|c|c|c|c|}
\hline $\mathbf{Q}$ & \multirow[t]{2}{*}{ Theme } & \multicolumn{2}{|c|}{$\begin{array}{c}\text { Triangulation based on the available } \\
\text { sources }\end{array}$} \\
\hline $\begin{array}{l}\mathbf{S} \\
\mathbf{T} \\
\mathbf{I} \\
\mathbf{O} \\
\mathbf{N}\end{array}$ & & Teacher's Responds & $\begin{array}{l}\text { Document } \\
\text { Review }\end{array}$ \\
\hline Q1 & $\begin{array}{l}\text { 1. A slight increase } \\
\text { number of failure } \\
\text { rate statistics. }\end{array}$ & $\begin{array}{l}\text { Teacher's agreed } \\
\text { that based on the } \\
\text { statistics in }\end{array}$ & \\
\hline
\end{tabular}

\begin{tabular}{|c|c|c|c|}
\hline & & $\begin{array}{l}\text { mid-term of } 2019 \\
\text { there's a slight } \\
\text { increase number of } \\
\text { failure student in } \\
\text { reading literacy } \\
\text { compared to } \\
\text { numeracy. }\end{array}$ & $\begin{array}{l}\text { Programme of } \\
100 \% \text { Literacy } \\
\text { (PINCH) Jan } \\
2019- \\
\text { Percentage of } \\
\text { Pass in Reading }\end{array}$ \\
\hline Q2 & $\begin{array}{l}\text { 1.Sounds not clear } \\
\text { 2. RLIG need more } \\
\text { learning activities. } \\
\text { 3. Less focus on } \\
\text { content } \\
\text { 4. High level of } \\
\text { instruction } \\
\text { 5. Content not } \\
\text { similar to a latest } \\
\text { syllabus } \\
\text { 6. Some games are } \\
\text { very easy, and some } \\
\text { so challengeable } \\
\text { 7. Games must have } \\
\text { narrative stories, } \\
\text { challenges, rewards. }\end{array}$ & $\begin{array}{l}\text { Five of the teachers } \\
\text { explained } \\
\text { interactive games } \\
\text { need to be well } \\
\text { design with } \\
\text { integrating some } \\
\text { important elements } \\
\text { and theories. }\end{array}$ & $\begin{array}{l}=91.46 \% \text { and } \\
\text { Failure in } \\
\text { Reading } \\
\text { Literacy is } \\
=8.54 \% \\
\text { Other subject } \\
\text { failures rate } \\
(\%) \text { : } \\
\text { a) Numeracy } \\
=2.73 \% \\
\text { Registered }\end{array}$ \\
\hline Q3 & $\begin{array}{l}\text { 1. The use of } \\
\text { interactive games in } \\
\text { reading literacy } \\
\text { could help to } \\
\text { increase student's } \\
\text { engagement. } \\
\text { 2. Interactive games } \\
\text { attract students and } \\
\text { teacher to involve } \\
\text { intensely in reading } \\
\text { literacy learning. } \\
\text { 3. A monitoring or } \\
\text { control factor is } \\
\text { needed to avoid any } \\
\text { excessive use of } \\
\text { technology. } \\
4 \text {. The use of } \\
\text { interactive games } \\
\text { could help teacher in } \\
\text { delegating activities } \\
\text { learning to be done } \\
\text { after the class hour. }\end{array}$ & $\begin{array}{l}\text { Most of teachers } \\
\text { realized that } \\
\text { students pay their } \\
\text { attention during } \\
\text { reading literacy } \\
\text { class once the } \\
\text { teachers start use } \\
\text { interactive games. } \\
\text { After the playing } \\
\text { interactive games, } \\
\text { teachers get good } \\
\text { respond from the } \\
\text { students. } \\
\text { Most of the teachers } \\
\text { expressed that the } \\
\text { use of interactive } \\
\text { games to support } \\
\text { reading literacy } \\
\text { learning process is } \\
\text { quite interesting and } \\
\text { indirectly support } \\
\text { the student's } \\
\text { engagement in } \\
\text { learning. }\end{array}$ & $\begin{array}{l}\text { P1NCH } \\
\text { Screening Test, } \\
\text { Jan } 2019= \\
107706 \text { students }\end{array}$ \\
\hline
\end{tabular}

The responses from the five teachers who are from five different primary schools are summarised under the third column in the table. The fourth column is a summary of the overall achievements in Reading Literacy subject and other's subject (Numeracy) failures percentage in Primary School's P1NCH screening test, Jan 2019 in the state of Johore. These two sources were then triangulated to identify the theme. The details of the findings are elaborated in this section for each segment of interview questions. From the supporting documents of the Primary School's P1NCH screening test, Jan 2019, the teachers have agreed that there's a slight increase in the student's failure rates, as compared to Numeracy. 
All the teachers point out that the existing interactive game has some problem such as unclear sound, high level of instruction, lack of learning content lead to pupil not mastering skills. Existing games also do not have narrative stories that allow students to quickly understand the topic and read the word. Elements of reward and challenges are also less emphasize to cause students less focus and motivate to learn.

According to the teachers, students understand better through learning by interactive games, which prove to be more effective. The students usually focus, engaged on learning. After the L\&T via interactive games, the teacher starts the question and answer activity. The stated engagement during learning by interactive games and during the question and answer activity shows that the students are much more interested in the learning via RLIG rather than reading the textbook. Reinforce by playing RLIG during reading literacy learning can prove to be a much more useful approach in gaining the students attention, and to understand the subject better. The teachers' reaction at being questioned whether it is possible to have RLIG for reading literacy subject seems positive. The teachers believe that the RLIG can support the students' engagement, and allows both the teacher and the students to be involved. As for the students, most of them are also skillful in using digital devices. This creates an opportunity and platform for both groups to participate in the educational game. However, the designers must give important such as thing like integrating latest syllabus content, user-friendly designing, implementation of theories in RLIG so that students can achieve the reading literacy well.

\section{CONCLUSION}

Figure 2 is a proposed theoretical framework for this study. Aspects of the mastery and achievement of students in reading literacy, the involvement of students in learning and students interest in reading literacy are focused on this study. Jonassen's Constructivism Learning Theory (2013), will be applied in this study. According to this theory, learning is generative, that is, building a concept or meaning from what is being learned (Jonassen, 2013). Bellotti et al., (2013), states that constructivism theory is a strategic guide to building interactive games. interactive game based experience will make players more dynamic. Based on that concept, the aspects of Constructivism such as the activism of building new knowledge based on past experience, comparing new information with its past understanding and adapting old experiences with new information to create new concepts will be focused on this study (Jonassen, 2013).

The 'Five Engaging Elements' game model by Kapp (2016), will be used in this study to build interactive games. Kapp (2012), states its model based on constructivism theory. Bottino et. al (2013), supports the opinion stating that the Kapp model (2012), is a game model that emphasizes learning that builds on experience as emphasized in constructivism theory. Five elements emphasized in the game by Kapp (2012) are narrative stories, opportunities, challenges, reinforcement and design are effectively implemented in interactive games to enhance reading skills among students.

Technical issues in interactive games and issues of classroom execution are key factors for interactive games that can no longer be regarded as a key tool in learning and teaching reading skills. In this research, the researcher will address the identified technical problems and issues of interactive game implementation for reading skills and producing interactive games that give a good impact on students learning. The interactive game design will focus on learning theories, learning strategies and game elements so that student's achievement, student's engagement and student's interest can be improved in learning reading skills.

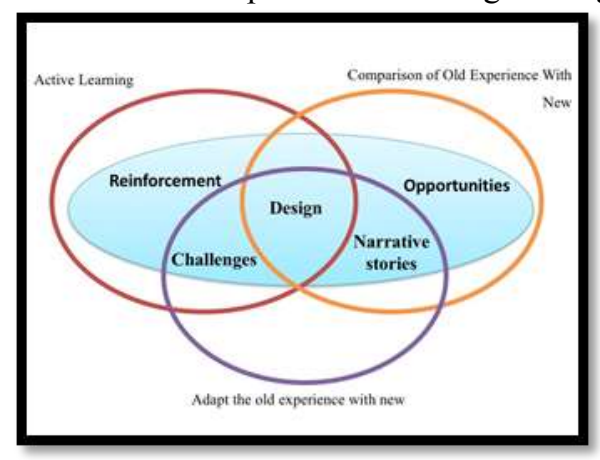

Fig II: Theoretical Framework

\section{ACKNOWLEDGMENT}

The authors would like to thank University Teknologi Malaysia for their support in making the project possible. This work was support in making this project possible. This work was supported by Research University Grant by University Teknologi Malaysia.

\section{REFERENCES}

1. Craft, A. (2012). Childhood in a Digital Age: Creative Challenges for Educational Futures. London Review of Education 10 (2), 173-190.

2. Crawford, C. (2013). The Art of Interactive Design SanFrancisco: No Starch Press.

3. Dechant, E. (2013). Diagnosis and Remediation of Reading Disabilities. United States of America: Prentise Hall.

4. Delacruz, G. C. (2011). Games as formative assessment environments: Examining the impact of explanations of scoring and incentives on math learning, games performance, and help seeking. National Center for Research on Evaluation, Standards, and Student Testing.

5. Divjak, B. (2015). The Impact of Game-Based Learning On the Achievement of Learning Goal and Motivation for Learning Mathematics. JIOS, 1, 15-30.

6. Gary, Bitter, G., Jane, \& Legacy, M. (2016). Using technology in the classroom. Boston: Pearson Allyn \& Bacon.Ltd.

7. Gee, J. P. (2016). Deep learning properties of good digital games: How far can they go? Serious games: Mechanisms and effects.

8. Genc Ilter, B. (2010). Effect of Technology on Motivation in EFL Classrooms. Turkish Online Journal of Distance Education, 10.

9. Jonassen, D., Peck, K., \& Wilson, B. (2014). Learning with technology: A constructivist perspective. Upper Saddle River: New Jersey Prentice Hall. 
10. Kapp, K. (2012). Gamification: Separating Fact From Fiction. United States of America: Library of Congress

11. Kapp, K. (2016). Gadgets, Games and Gizmos for Learning: Tools and Techniques for Transferring Know-How from Boomers to Gamers. United States of America: Library of Congress

12. Meng, E. A. (2014). Education Series : Professionalism of Teacher Semester 2. Selangor Penerbit Fajar Bakti.

13. Miles. (2014). Learning to Play Like a Human: Case Injected Genetic Algorithms for Strategic Computer Gaming. Congress on Evolutionary Computation (CEC2004), 2, 1441-1448.

14. Misbah, F. (2012). Kajian tindakan meningkatkan penguasaan membaca murid Tahun Satu (LINUS) menggunakan kaedah Gabungan Bunyi Kata dengan Teknik Latih. SK Sri Suria 2, Tanah Merah, Kelantan. IPG Tengku Razali, Kelantan.

15. Mohd Hilmy. (2012). Pengajaran Dan Pemebelajaran Bahasa Malaysia Di Sekolah-Sekolah Rendah. Kuala Lumpur: Dewan Bahasa Dan Pustaka.

16. Muhamad Hassan, A. R. (2014). Kesedaran metakognitif membaca dan pencapaian akademik mata pelajaran bahasa. Jurnal pendidikan 2014, 21.

17. Munirah, G. (2015). Diagnosis of pupils' learning difficulties in primary schools mathematics. International Conference on Measurement and Evaluation in Education, 11.

18. Noor Azzam, A. R. (2009). Pelaksanaan program Nilam dalam pengajaran bahasa Melayu sekolah menengah di Negeri Sembilan. Universiti Putera Malaysia, Serdang.

19. Noor Sharezza Azzura, S. (2014). The Effect Of Computer Based Instructional Games In Teaching Subject Verb Agreement. (Master Thesis Page 97), UTM, Skudai.

20. Noriati, A. R., Yong, B. P., \& Fakriah, S. (2012). Murid dan alam belajar. Shah Alam: Oxford Fajar Sdn Bhd.

21. Papastergiou, (2014). Thinking and cognitive development in young children. London SAGE Publication.

22. Sanai, M. (2013). Celik huruf: Lancar baca. Buku Koleksi Kerja Seminar Penyelidikan IPGM KBL.

23. Sharifah, R. A. (2010). Kanak-kanak pemulihan, masalah-masalah, punca-punca dan strategi pengajaran dalam pendidikan pemulihan. Kertas Kerja Seminar Pendidikan bagi Pegawai-Pegawai Pelajaran Negeri dan Pejabat Pelajaran Daerah, 21.

24. Stapa, S. H., Nadzrah, A. B., \& Rozmel, A. L. (2013). Literasi Bahasa Inggeris dalam kalangan murid luar bandar: Implikasi terhadap pengajaran dan pembelajaran. Jurnal e-Bangi, 2.

25. Steinberg, D.D. (2012). Psycholinguistic: Language, Mind And Word. London: Longman.

26. Truscott. (2010). The impact of mind game playing on children's reasoning abilities: reflections from an experience. (Vol. 2). England: Academic Publishing Ltd. Reading.

27. Wah, L. L., Manisah, M. A., \& Salleh, N. (2013). Pembinaan dan pengesahan ujian membaca perkataan dan ujian mengeja untuk tujuan mengenal pasti disleksia: Satu kajian rintis. Jurnal Pendidik dan Pendidikan, 23.

28. Wang, C. L. W. (2012). Artikell Penyelidikan Tindakan PISMP SN amb. Januari 2009,. Seminar Penyelidikan Tindakan IPG KBL, 87-90

29. Ya-Ting. (2012). Building virtual cities, inspiring intelligent citizens: digital games for developing students' problem solving and learning motivation. Computers and Education, 59.

30. Zulzana Zulkarnain. (2012). Hubungan antara minat, sikap dengan pencapaian pelajar dalam kursus CC301 Quantity Measurement. Politeknik Port Dickson.

31. Zyda, M. (2015). From visual simulation to virtual reality to games. Compute Perspectives. IEEE Computer Society. September 2015 